\title{
Simultaneous evaluation of four PCR primer sets for the diagnosis of Streptococcus phocae infection
}

\author{
R. Avendaño-Herrera
}

Laboratorio de Veterquímica, Camino Melipilla 5641, Cerrillos, Santiago, Chile

\begin{abstract}
The sensitivity of 4 published primer pairs for the detection of Streptococcus phocae strains was evaluated. Primer sets cpn60-F and -R and sodA-F and -R correctly identified S. phocae. Correct identification was also achieved with the primer pairs cae1-cae2 and PX1-PX2, but using the reverse complementary version of both reverse primers (caeVQ2 and PXVQ2, respectively). Among the 4 PCR protocols with pure and mixed cultures, the primer pair PX1-PXVQ2 provided the highest level of sensitivity for $S$. phocae $\left(10^{2}\right.$ and $10^{4}$ cells per PCR tube), and detection was 10 - to 100-fold higher than the other 3 primer pairs. When the cae1-caeVQ2 and PX1-PXVQ2 PCR protocols were applied to different seeded Atlantic salmon tissues (spleen, kidney and liver), the detection limit achieved was $5.1 \times 10^{5}$ to $6.4 \times 10^{7} \mathrm{CFU} \mathrm{g}^{-1}$, and the lowest sensitivity detected was $1.18 \times 10^{6} \mathrm{~S}$. phocae per tube (which corresponds to $6.4 \times 10^{7} \mathrm{CFU} \mathrm{g}{ }^{-1}$ ) in spleen samples using PX1-PXVQ2. In the kidney samples seeded with $S$. phocae strains, regardless of the primer set used, the PCR sensitivity was the same $\left(7.31 \pm 1.5 \times 10^{6} \mathrm{CFU} \mathrm{g}^{-1}\right)$. In addition, the nested PCR assay using the primer pair PX1-PXVQ2 improved the sensitivity of detection of $S$. phocae by at least 100 times compared to the first round PCR, not only in mixed and pure suspensions, but also in experimentally seeded fish tissues. The picked tissues that allowed the easiest detection of $S$. phocae were the liver, kidney and spleen, respectively. Thus, the nested PCR approach is an important tool for the rapid and reliable diagnosis of streptococcosis due to $S$. phocae.
\end{abstract}

KEY WORDS: Streptococcus phocae $\cdot \mathrm{PCR} \cdot$ Nested PCR $\cdot$ Diagnosis

\section{INTRODUCTION}

Streptococcus phocae, a member of the pyogenic streptococcal group (Köhler 2007), is an important emerging pathogen for salmonid culture in southern Chile, being recently included as a new member of the warm water streptococcosis syndrome (Romalde et al. 2008). This pathogen was first isolated from pinnipeds (Skaar et al. 1994, Henton et al. 1999, Vossen et al. 2004, Kuiken et al. 2006). Later, Gibello et al. (2005) identified some strains from diseased Atlantic salmon Salmo salar as Streptococcus phocae. To date it is one of the most important risk factors in the salmon industry in Chile during summer months when infections can result in 3 to $25 \%$ cumulative mortality of the affected population (Romalde et al. 2008). The mortality is limited, but the disease has economic significance due to lowered quality of fish as well as the high costs of antimicrobial agents, mainly erythromycin, which contribute greatly to a rapid reduction of the mortality in fish.

Streptococcosis, due to Streptococcus phocae, is currently detected by exophthalmia with accumulation of purulent and haemorragic fluid around eyes, by ventral petechial haemorrhages and by skin abscess in affected fish (Romalde et al. 2008). The precise diagnosis of the disease must be supported by the isolation of S. phocae from fish tissues, a task that in some cases can be very difficult to perform due to the overgrowth produced by several other bacterial species present within the lesions. The traditional culture-based method for the detection of the pathogen requires several days before results are obtained. Moreover, misidentifications of $S$. phocae strains using the miniaturized system Rapid ID 32 Strep have been reported (Gibello et al. 2005, Romalde et al. 2008). Economic 
damages for fish farmers are severe and can be augmented due to delay or misinterpretation of the disease diagnosis.

A method that is rapid and precise in detecting and identifying the pathogen is, therefore, crucial for the effective management and disease control in fish farming. Until now, 4 PCR primer pairs have been designed for the detection of Streptococcus phocae. Alber et al. (2004) selected the genes sodA encoding the bacterial superoxide dismutase $\mathrm{A}$, and cpn60 encoding chaperonin 60, which could differentiate $S$. phocae from numerous Streptococcus species. More recently, Hassan et al. (2008) designed a further 2 protocols using the 16S ribosomal RNA and 16S-23S rDNA intergenic spacer as targets. However, neither Alber et al. (2004) nor Hassan et al. (2008) determined the actual limits of each primer set with pure and mixed cultures, as well as in fish samples.

The present study examined the sensitivity of the 4 PCR methods described previously for the identification of Streptococcus phocae. We also describe a nested PCR approach, which was evaluated experimentally by seeded fish tissues.

\section{MATERIALS AND METHODS}

Bacterial strains. The bacterial strains used in the present study included the type strain Streptococcus phocae ATCC $51973^{\mathrm{T}}$ (equivalent to DSMZ $15635^{\mathrm{T}}$ ) isolated from seal in Norway, and 4 S. phocae strains (Au14, Au15, PF-132 and PF-134) isolated from diseased Atlantic salmon in Chile (Romalde et al. 2008). These strains were chosen as representative of $S$. phocae because previous studies (Romalde et al. 2008, Valdés et al. 2008) demonstrated that the salmon isolates are phenotypically, antigenically and genetically homogeneous. The bacteria were routinely grown on
Columbia sheep blood agar plates (CSB, AES Laboratoire) and incubated aerobically at $37^{\circ} \mathrm{C}$ for 24 to $48 \mathrm{~h}$. Stock cultures were maintained frozen at $-70^{\circ} \mathrm{C}$ in Criobilles tubes (AES Laboratoire).

DNA extraction. Chromosomal DNA was extracted for subsequent analysis using 2 different commercial systems: InstaGene Purification Matrix (Bio-Rad Laboratories) for pure cultures and Dynabeads DNA Direct (Dynal) for tissue samples. In all cases, DNA purification was performed according to the manufacturer's instructions. From each DNA sample extracted, $1 \mu \mathrm{l}$ was used directly for single and nested PCR amplification and the remaining DNA sample was maintained at $-20^{\circ} \mathrm{C}$.

Confirmation and assignment of strain species. To confirm the designation as Streptococcus phocae, initially each strain was tested using the primer pairs cpn60F-cpn60R and sodAF-sodAR designed by Alber et al. (2004) and cae1-cae2 and PX1-PX2 described by Hassan et al. (2008) (Table 1). These and all other PCR assays described hereafter were performed in a Thecne thermal cycler (Barloworld Scientific) using the commercial kit Ready-To-Go PCR beads (Amersham Pharmacia Biotech), which included all the reagents needed for the PCR reactions (buffer, nucleotides and Taq DNA polymerase) with the exception of the specific primers and DNA template. PCR amplifications were performed in $25 \mu \mathrm{l}$ reactions mixture containing $0.4 \mu \mathrm{M}$ of each primer, $1 \mu \mathrm{l}$ of the template and $22 \mu \mathrm{l}$ of sterile distilled water. The amplification protocol for cpn60F and -R was as follows: $94^{\circ} \mathrm{C}$ for $180 \mathrm{~s}$ followed by 30 cycles at $94^{\circ} \mathrm{C}$ for $30 \mathrm{~s}, 60^{\circ} \mathrm{C}$ for $40 \mathrm{~s}$ and $72^{\circ} \mathrm{C}$ for $45 \mathrm{~s}$, with a final extension of $72^{\circ} \mathrm{C}$ for $300 \mathrm{~s}$. For sodAF and -R: 1 denaturation cycle at $94^{\circ} \mathrm{C}$ for $180 \mathrm{~s}$ followed by 30 cycles at $94^{\circ} \mathrm{C}$ for $30 \mathrm{~s}, 60^{\circ} \mathrm{C}$ for $40 \mathrm{~s}$ and $72^{\circ} \mathrm{C}$ for $45 \mathrm{~s}$, terminated by 1 cycle at $72^{\circ} \mathrm{C}$ for $300 \mathrm{~s}$. For amplification of 16S-23S rDNA the cycling conditions consisted of a denaturation cycle at $94^{\circ} \mathrm{C}$ for $240 \mathrm{~s}$ followed

Table 1. Primers used to confirm and assign Streptococcus phocae strain species

\begin{tabular}{|c|c|c|c|c|}
\hline Target gene & Primer & Sequence $\left(5^{\prime}-3^{\prime}\right)$ & $\begin{array}{l}\text { Amplicon } \\
\text { size (bp) }\end{array}$ & Source \\
\hline cpn60 & $\begin{array}{l}\text { cpn60-F } \\
\text { cpn60-R }\end{array}$ & $\begin{array}{l}\text { CCGAGGGATTGAAAAAGCTAGCTTA } \\
\text { AGATAAATGGGTTTTCTAATTCTGCC }\end{array}$ & 311 & Alber et al. (2004) \\
\hline $\operatorname{sodA}$ & $\begin{array}{l}\text { sodA-F } \\
\text { sodA-R }\end{array}$ & $\begin{array}{l}\text { CATTGTTAGCAGATGTTGATGCGATA } \\
\text { ATAGGCTTTTTACCATCTGAGATTGG }\end{array}$ & 322 & Alber et al. (2004) \\
\hline 16S-23S rDNA & $\begin{array}{l}\text { cae1 } \\
\text { cae2 } \\
\text { caeVQ2 }\end{array}$ & $\begin{array}{l}\text { AAGCACGTTAGGAAAATG } \\
\text { CGAAGTCATAAAAATAGTATG } \\
\text { CATACTATTTTTATGACTTCG }\end{array}$ & 180 & $\begin{array}{l}\text { Hassan et al. (2008) } \\
\text { Present study }\end{array}$ \\
\hline 16S rRNA & $\begin{array}{l}\text { PX1 } \\
\text { PX2 } \\
\text { PXVQ2 }\end{array}$ & $\begin{array}{l}\text { GCTAATACCGCATAAGAAGAG } \\
\text { GAGCAGAAGTGACAGGGTG } \\
\text { CACССTGTCACTTCTGCTC }\end{array}$ & 900 & $\begin{array}{l}\text { Hassan et al. (2008) } \\
\text { Present study }\end{array}$ \\
\hline
\end{tabular}


by 30 cycles at $92^{\circ} \mathrm{C}$ for $30 \mathrm{~s}, 48^{\circ} \mathrm{C}$ for $30 \mathrm{~s}$ and $72^{\circ} \mathrm{C}$ for $30 \mathrm{~s}$; the final cycle was followed by an extension at $72^{\circ} \mathrm{C}$ for $300 \mathrm{~s}$. Finally, the PCR for the 16 rRNA gene was carried out using an initial denaturation step at $94^{\circ} \mathrm{C}$ for $240 \mathrm{~s}$ with 35 cycles of $94^{\circ} \mathrm{C}$ for $90 \mathrm{~s}$, annealing at $60^{\circ} \mathrm{C}$ for $90 \mathrm{~s}$ and extension at $72^{\circ} \mathrm{C}$ for $90 \mathrm{~s}$, with a final extension step at $72^{\circ} \mathrm{C}$ for $300 \mathrm{~s}$. In all cases, negative controls, consisting of the same reaction mixture but with sterile distilled water instead of template DNA, were included in each batch of PCR reaction.

Analysis of PCR products. The presence of PCR products was determined by electrophoresis of $1.5 \%$ $(\mathrm{w} / \mathrm{v})$ agarose gel for $60 \mathrm{~min}$ at $100 \mathrm{~V}$ in TAE1X (0.04 M Tris, 0.0001 M EDTA, pH 8.0), visualized with ethidium bromide (Bio-Rad) and photographed under UV light. A 100-bp DNA ladder (Bioron) was used as a molecular mass marker. Reproducibility of results was assessed by repetition in at least 2 independent PCR assays. The presence of a single product of the appropriate fragment size (Table 1), identical to the reference strains, was considered a positive result for Streptococcus phocae.

Determination of PCR sensitivity. The detection limits of each primer set (cpn60F-cpn60R, sodAF-sodAR, cae1-caeVQ2 and PX1-PXVQ2) were evaluated in sensitivity assays using pure or mixed cultures as described by Avendaño-Herrera et al. (2004). Separate bacterial suspensions of the 5 Streptococcus phocae strains were prepared to contain $10^{9}$ cells ml $^{-1}$ (McFarland Scale 4) and were 10 -fold diluted in $0.85 \%$ sterile saline solution from $10^{8}$ to 10 cells ml ${ }^{-1}$. To determine the usefulness of the primer sets to amplify template DNA of $S$. phocae from mixed cultures, bacterial suspensions of Vibrio anguillarum, V. ordalii and Aeromonas salmonicida were employed. These bacteria were selected because they are some of the pathogens reported in Chile which could interfere with the detection of the $S$. phocae from infected fish. Thus, bacterial mixtures of $S$. phocae with 2 different fish pathogens were prepared for PCR sensitivity testing. To each dilution of $S$. phocae strain, $100 \mu$ of 2 of the nonStreptococcus bacterial suspensions mentioned above, containing approximately $10^{8}$ cells $\mathrm{ml}^{-1}$, was added. Chromosomal DNA was extracted as described previously, and CFU ml ${ }^{-1}$ were estimated in all cases by plating onto CSB agar. Conditions for PCR amplification and electrophoresis were as previously described. Limits of detection were determined based on presence or absence of PCR products on gels.

Determination of PCR sensitivity from seeded fish samples. On the basis of the results obtained using bacterial cultures only, 3 Streptococcus phocae strains (Au15, PF132 and type strain) were used. PCR sensitivity was determined employing DNA extracted from in vitro seeded spleen, kidney and liver as described by
Avendaño-Herrera et al. (2004) and using the reverse complementary version of the reverse primer given by Hassan et al. (2008). Briefly, tissue samples were taken from healthy Atlantic salmon using aseptic technique and divided in 4 (spleen), 35 (kidney) and 50 (liver) mg pieces. Each fish sample was seeded with $100 \mu$ l of different dilutions (from $10^{8}$ to $10^{2}$ cells ml$^{-1}$ ) of a pure and mixed culture and homogenized in phosphate buffered saline (PBS, pH 7.4) for $60 \mathrm{~s}$. After incubation for $1 \mathrm{~h}$ at $18^{\circ} \mathrm{C}$, DNA was extracted in $200 \mu \mathrm{l}$ using Dynabeads DNA Direct (Dynal) following the manufacturer's instructions. Non-inoculated samples, employed as negative controls, were processed in the same manner but with sterile saline solution instead of bacterial dilutions. For the PCR, $1 \mu$ l of the purified DNA was added as the template. Again, limits of detection were determined based on presence or absence of PCR products on gels.

Nested PCR amplification. To increase the sensitivity of the 16S rDNA PCR assay described in Hassan et al. (2008), a nested PCR was conducted on the whole dilution series from pure and mixed cultures as well as on the seeded tissues described above. The first round of PCR was performed using Ready-To-Go PCR beads and the universal primers 20F (5'-AGA GTT TGA TC(AC) TGG CTC AG-3') and 1500R (5'-GGT TAC CTT GTT ACG ACT T-3') according to the protocol described by Weisburg et al. (1991). After the first amplification by external primers, each PCR product was diluted 1:10 in sterile distilled water and $1 \mu$ used as a template for the second amplification by the speciesspecific primer set PX1-PXVQ2. In this step, the number of cycles was shortened to 30 cycles of amplification. The PCR samples were examined by gel electrophoresis and the samples were considered positive if the anticipated $900 \mathrm{bp}$ product was observed. Results of the nested PCR were compared with results from the direct PCR using the PX1-PXVQ2 primer pair to determine relative limits of detection.

\section{RESULTS AND DISCUSSION}

One of the most critical steps in the study of bacterial fish diseases is the correct identification of the infectious agent. Diagnosis of streptococcosis is mainly based on the study of phenotypical traits of the isolated bacteria (Romalde et al. 2008), but the methodology is time consuming. In addition, obtaining pure cultures of Streptococcus phocae from ulcers and internal organs, with the exception in some cases of kidney, is difficult due to the presence of faster growing bacteria. On the other hand, although the disease presents a rapid course with appearance of clinical signs in 1 or $2 \mathrm{~d}$, in acute cases fish can show no symptoms (Romalde et al. 


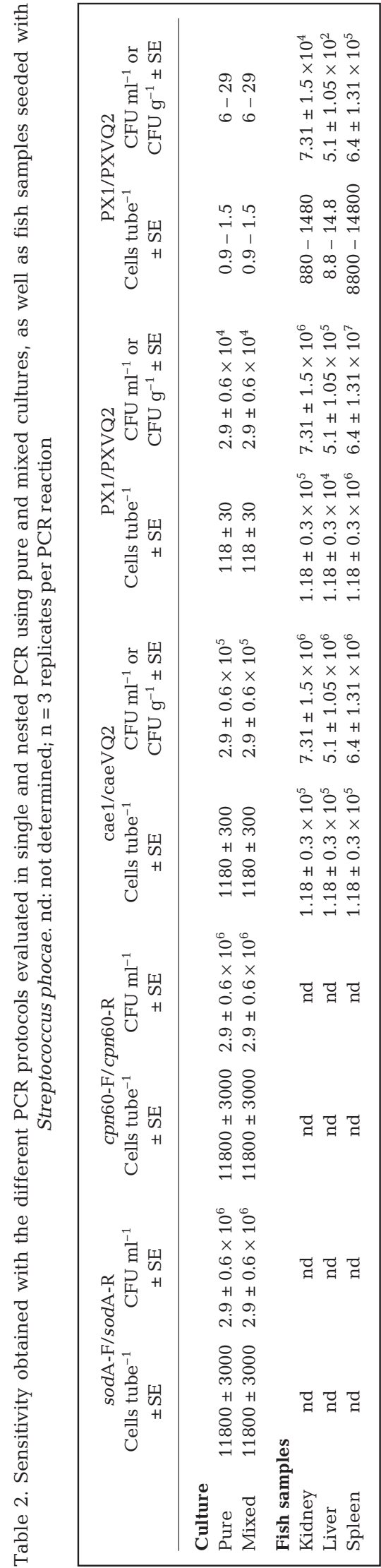

2008). To overcome these difficulties, 4 PCR assays have been developed in recent years as tools for diagnosis, based on the amplification of the genes encoding the bacterial superoxide dismutase A, chaperonin 60, 16S rRNA and 16S-23S rRNA. However, until now the sensitivity of these primer sets have not been evaluated in parallel in order to propose the best PCR proto$\mathrm{col}$ to detect this pathogen in research laboratories.

The primers cpn60F and -R and sodAF and -R correctly identified Streptococcus phocae with the amplicon sizes given by Alber et al. (2004) (data not shown). $S$. phocae was also correctly identified with the oligonucleotide primers given by Hassan et al. (2008) (reverse complementary version of sequences given), which were used to perform the sensitivity studies.

Detection limits in pure culture of each PCR from different bacterial suspension $\left(10^{8}\right.$ to 10 cells ml $\left.{ }^{-1}\right)$ of the 3 Streptococcus phocae strains were between $10^{2}$ and $10^{4}$ cells per PCR tube (Table 2). Among the 4 PCR protocols, the PX1-PXVQ2 primer pair provided the highest level of sensitivity for $S$. phocae, and detection was 10 - to 100-fold higher than that observed with the other 3 primer pairs (Fig. 1, lanes 1 to 4 ). It is not surprising that the low levels of detection obtained when both sodA and cpn60 genes for PCR were used as targets (about $10^{4}$ bacteria per PCR tube, $2.9 \pm 0.6 \times 10^{6}$

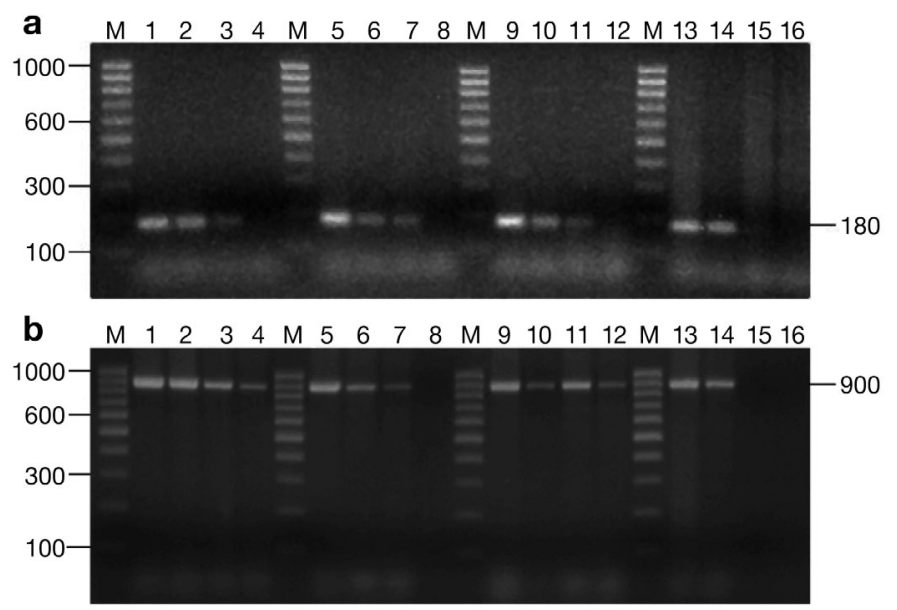

Fig. 1. Streptococcus phocae. Sensitivity of the PCR protocols with (a) cae1-caeVQ2 and (b) PX1-PXVQ2 primer sets. Lane M: molecular ruler (100 bp ladder, Invitrogen); Lanes 1 to 4 : serial dilutions of the chromosomal DNA from extracted from S. phocae ATCC $51973^{\mathrm{T}}, 1 \times 10^{8}$ (Lane 1 ) to $1 \times 10^{5}$ (Lane 4 ) cells $\mathrm{ml}^{-1}$; Lanes 5 to 8: DNA extracted from kidney seeded with 10 -fold dilutions of the type strain ATCC $51973^{\mathrm{T}}, 7.3 \times$ $10^{7}$ (Lane 5) to $7.3 \times 10^{4}$ (Lane 8) $\mathrm{CFU} \mathrm{ml}^{-1}$; Lanes 9 to 12 : amplified DNA extracted from seeded liver samples, $5.1 \times 10^{7}$ (Lane 9) to $5.1 \times 10^{4}$ (Lane 12) $\mathrm{CFU} \mathrm{ml}^{-1}$; Lanes 13 to 16 : amplified DNA extracted from seeded spleen samples, $6.4 \times 10^{8}$ (Lane 13) to $6.4 \times 10^{5}$ (Lane 16) $\mathrm{CFU} \mathrm{ml}^{-1}$. Left $y$-axis: position of molecular size marker $(\mathrm{bp})$; right $y$-axis: size of specific amplified products (bp) 
$\mathrm{CFU} \mathrm{m} \mathrm{m}^{-1}$ ), since the number of copies should be lower than for the 16S rRNA gene and the 16S-23S rDNA intergenic spacer.

When DNA extracted from mixed cultures was used as a template, limits of detection of Streptococcus phocae strains were identical to the level of amplification obtained with DNA from pure cultures (Table 2). Although the sensitivity and specificity of the PCR detection for target bacteria can be reduced in mixed cultures (Lee et al. 1995), it was observed that the other fish pathogens assayed did not affect the PCR, even when $9.1 \pm 2 \times 10^{6} \mathrm{CFU} \times \mathrm{ml}^{-1}$ of each species was employed.

Based on the best sensitivity found in pure and mixed cultures, only the primer pairs cae1-caeVQ2 and PX1-PXVQ2 were tested with DNA extracted from the experimentally seeded fish tissues. The detection limit achieved was $5.1 \times 10^{5}$ to $6.4 \times 10^{7} \mathrm{CFU} \mathrm{g}^{-1}$, and when results were obtained for spleen samples the lowest sensitivity detected was $1.18 \times 10^{6}$ Streptococcus phocae per tube using PX1-PXVQ2 (Fig. 1, lanes 13 to 16). Our results also indicated that, for infected liver, the level of detection for the 16S rDNA PCR ranged from $5.1 \pm 1.05 \times 10^{5} \mathrm{CFU} \mathrm{g}^{-1}$ and was more sensitive than PCR with the cae1-caeVQ2 primer set (Fig. 1, lanes 9 to 12). Note that in the kidney samples seeded with $S$. phocae strains, regardless of the primer set used, the PCR sensitivity was the same (Table 2). Non-inoculated salmon tissues were always PCR-negative. The sensitivity observed with fish tissues was lower than that observed with pure and mixed cultures and can be explained by the presence of host DNA and an undefined inhibitor of the PCR reaction (Wilson 1997). The sensitivity of the $16 \mathrm{~S}$ DNA-based PCR amplification assay is probably sufficient to detect $S$. phocae acute infections in fish, but not when the pathogen is present in asymptomatic carrier fish or when it is present in very low numbers.

The nested PCR approach tested increased the sensitivity of detection by 2 to 3 orders of magnitude compared to conventional PCR, regardless of the type of samples employed (Fig. 2). When $1 \mu$ l (diluted 1:10) of the first-round product amplified with the $20 \mathrm{~F}$ and $1500 \mathrm{R}$ primer set was used as a template for speciesspecific primers in the nested PCR assay, the detection level for pure and/or mixed cultured Streptococcus phocae was at least 1 cell per reaction (equivalent to $2.9 \pm 0.6 \times 10^{1} \mathrm{CFU} \mathrm{m \textrm {m } ^ { - 1 }}$ ). Moreover, the protocol allowed the detection of $5.1 \times 10^{2}$ to $6.4 \times 10^{5} \mathrm{CFU} \mathrm{g}^{-1}$ using tissue seeded with a pure bacterial suspension. It also allowed the detection of $S$. phocae when using first-round amplification products without diluting, but unspecific amplicons of higher molecular weight appeared from DNA extracted from all samples, with the exception of spleen tissue (data not shown).

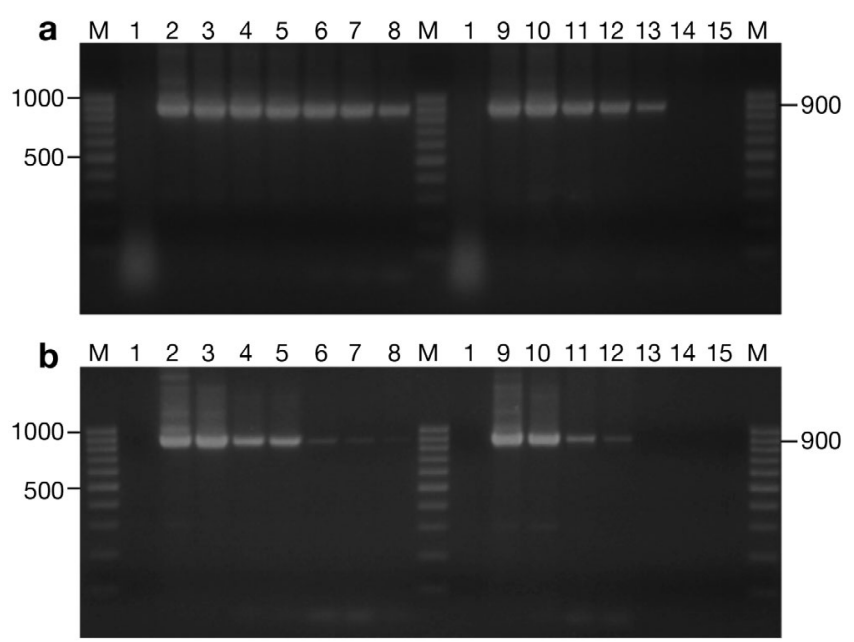

Fig. 2. Streptococcus phocae. Analysis of the limit of S. phocae detection by nested PCR amplification. (a) Mixed cultures and kidney. Lane M: molecular ruler (100 bp ladder, Invitrogen); Lane 1: negative control (no DNA); Lanes 2 to 8: DNA extracted from serial 10-fold dilution of the mixed cultures of the reference strain ATCC $51973^{\mathrm{T}}$ and 3 other fish pathogens, $1 \times$ $10^{8}$ (Lane 2) to $10^{2}$ (Lane 8) cells $\mathrm{ml}^{-1}$; Lanes 9 to 15 : DNA extracted from kidney seeded with decimal dilutions of the reference strain ATCC $51973^{\mathrm{T}}$ in pure culture, $7.3 \times 10^{7}$ (Lane 9) to $7.3 \times 10^{1} \mathrm{CFU} \mathrm{ml}^{-1}$ (Lane 15). (b) Liver and spleen. Lane M: molecular ruler (100 bp ladder, Invitrogen); Lane 1: negative control (no DNA and unseeded tissue); Lanes 2 to 8: DNA extracted from liver seeded with decimal dilutions, $5.1 \times 10^{7}$ (Lane 2) to $5.1 \times 10^{1}$ (Lane 8) $\mathrm{CFU} \mathrm{ml}^{-1}$; Lanes 9 to 15 : amplified DNA extracted from seeded spleen samples, $6.4 \times 10^{8}$ (Lane 9) to $6.4 \times 10^{2}$ (Lane 15) $\mathrm{CFU} \mathrm{ml}{ }^{-1}$. Left $y$-axis: position of molecular size marker (bp); right $y$-axis: size of specific amplified products (bp)

The method described allowed for an easy detection of Streptococcus phocae in liver samples with a level of sensitivity of $5.1 \pm 1.05 \times 10^{2} \mathrm{CFU} \mathrm{ml}{ }^{-1}$ (about 15 cells per tube). In the case of DNA extracted from spleen samples, the nested PCR method allowed the detection of 5.09 to $7.71 \times 10^{5} \mathrm{CFU} \mathrm{g}^{-1}$, showing an increase in sensitivity of 2 log units compared with the single amplification PCR from the spleen. A similar increase in sensitivity was detected in kidney tissues when nested PCR was used. The results of sensitivity obtained are in the same range as those obtained by a variety of PCR methods designed for other bacterial fish pathogens (Izumi \& Wakabayashi 1997, Osorio et al. 1999, Taylor \& Winton 2002, Avendaño-Herrera et al. 2004).

Since carrier fish probably constitute a significant reservoir for maintaining and spreading the diseases caused by Streptococcus phocae, this level of sensitivity should be sufficient for detecting subacute infection of potential carrier states in fish. However, considerably more work is necessary to propose its application 
as a non-destructive diagnosis approach, as well as confirmation of which tissue is the best target for PCR detection using natural samples from different fish farms.

The traditional microbiological approach (isolation plus identification) usually takes 3 to $4 \mathrm{~d}$ for definitive identification of Streptococcus phocae. The entire nested PCR assay proposed in the present study, including DNA extraction from samples, amplification and gel electrophoresis, is performed in $6 \mathrm{~h}$, and is more accurate than traditional methods because it is totally specific for $S$. phocae.

\section{CONCLUSIONS}

Based on the results from the present study, the PCR method utilizing the primer pair PX1-PXVQ2 proved to be more sensitive in detecting Streptococcus phocae than the other 3 PCR protocols, regardless of the type of samples employed. In addition, the nested PCR assay improved the sensitivity of detection of $S$. phocae by at least 100 times compared to single-round PCR, not only in mixed or pure bacterial suspensions, but also in experimentally seeded fish tissues. Although we found that all tissues sampled could be used to detect the bacterium with both PCR protocols, the experimentally seeded tissues that allowed the easiest detection were from the liver, kidney and spleen, respectively. Thus, the nested PCR approach is a valuable tool for the rapid and reliable diagnosis of streptococcosis due to $S$. phocae.

Acknowledgements. The author thanks I. Valdés for his technical help. This work was supported by Grant IPC 019 from the Program Bicentenario Ciencia y Tecnología, CONICYTChile. Also acknowledged are the anonymous reviewers, who provided many useful suggestions that improved this manuscript, and C. Lämmler for helpful comments.

\section{LITERATURE CITED}

Alber J, El-Sayed A, Lämmler C, Hassan AA, Vossen A, Siebert U (2004) Determination of species-specific sequences of superoxide dismutase A encoding gene sodA and chaperonin 60 encoding gene cpn60 for identification and phylogenetic analysis of Streptococcus phocae. Vet Microbiol 101:117-122

Avendaño-Herrera R, Magariños B, Toranzo AE, Beaz R, Romalde JL (2004) Species-specific polymerase chain

Editorial responsibility: Catherine Collins, Aberdeen, UK reaction primer sets for the diagnosis of Tenacibaculum maritimum infection. Dis Aquat Org 62:75-83

- Gibello A, Mata AI, Blanco MM, Casamayor A, Domínguez L, Fernández-Garayzabal JF (2005) First identification of Streptococcus phocae isolated from Atlantic salmon (Salmo salar). J Clin Microbiol 43:526-527

> Hassan AA, Vossen A, Lämmler C, Siebert U, FernándezGarayzabal JF (2008) PCR amplification of species-specific sequences of $16 \mathrm{~S}$ rRNA and 16S-23S rDNA intergenic spacer region for identification of Streptococcus phocae. Microbiol Res 163:132-135

Henton MM, Zapke O, Basson PA (1999) Streptococcus phocae infection associated with starvation in Cape fur seals. J S Afr Vet Assoc 2:98-99

Izumi S, Wakabayashi H (1997) Use of PCR to detect Cytophaga psychrophila from apparently healthy juvenile ayu and coho salmon eggs. Fish Pathol 32:169-173

Köhler W (2007) The present state of species within the genera Streptococcus and Enterococcus. Int J Med Microbiol 297:133-150

Kuiken T, Kennedy S, Barret T, Van de Bildt MWG and others (2006) The 2000 canine distemper epidemic in Caspian seals (Phoca caspica): pathology and analysis of contributory factors. Vet Pathol 43:321-338

> Lee CY, Pan SF, Chen CH (1995) Sequence of a cloned pR72H fragment and its use for detection of Vibrio parahaemolyticus in shellfish with the PCR. Appl Environ Microbiol 61: 1311-1317

> Osorio CR, Collins MD, Toranzo AE, Barja JL, Romalde JL (1999) 16S rRNA gene sequence analysis of Photobacteriumdamselae and nested PCR method for rapid detection of the causative agent of fish Pasteurellosis. Appl Environ Microbiol 65:2942-2946

Romalde JL, Ravelo C, Valdés I, Magariños B and others (2008) Streptococcus phocae, an emerging pathogen for salmonid culture. Vet Microbiol 130:198-207

Skaar I, Gaustad P, Tonjum T, Holm B, Stenwing H (1994) Streptococcus phocae sp. nov., a new species isolated from clinical specimens from seals. Int J Syst Bacteriol 44: 646-650

> Taylor PW, Winton JR (2002) Optimization of nested polymerase chain reaction assays for identification of Aeromonas salmonicida, Yersinia ruckeri, and Flavobacterium psychrophilum. J Aquat Anim Health 14:216-224

Valdés I, Jaureguiberry B, Romalde JL, Toranzo AE, Magariños B, Avendaño-Herrera R (2009) Genetic characterization of Streptococcus phocae strains isolated from Atlantic salmon (Salmo salar) in Chile. J Fish Dis (in press)

> Vossen A, Abdulmawjood A, Lämmler C, Weiß R, Siebert U (2004) Identification and molecular characterization of beta-hemolytic streptococci isolated from harbor seals (Phoca vitulina) and grey seals (Halichoerus grypus) of the German north and Baltic seas. J Clin Microbiol 42: 469-473

- Weisburg WG, Barns SM, Pelletier DA, Lane DJ (1991) 16S ribosomal DNA amplification for phylogenetic study. J Bacteriol 173:697-703

Wilson IG (1997) Inhibition and facilitation of nucleic acid amplification. Appl Environ Microbiol 63:3741-3751

Submitted: April 28, 2008; Accepted: October 1, 2008

Proofs received from author(s): December 16, 2008 